\title{
Pyrazole Derivatives as Corrosion Inhibitors for Steel in Hydrochloric Acid
}

\author{
L. Herrag, A. Chetouani, S. Elkadiri, B. Hammouti, ${ }^{*}$ A. Aouniti \\ Laboratoire de Chimie Appliquée \& Environnement, Faculté des Sciences, \\ Université Mohammed 1st, 60000 Oujda, Morocco
}

Received 17 May 2007; accepted 9 August 2007

\begin{abstract}
The effect of 1-\{[benzyl-(2-cyano-ethyl)-amino]-methyl $\}-5$-methyl-1H-pyrazole-3carboxylic acid methyl ester (P1) and 1-\{[benzyl-(2-cyano-ethyl)-amino]-methyl $\}-5$ methyl-1H-pyrazole-3-carboxylic acid ethyl ester (P2) was evaluated as corrosion inhibitors of steel in molar hydrochloric using weight loss measurements and electrochemical polarisation. The results obtained reveal that those compounds reduce the corrosion rate. The inhibiting action increases with the concentration of pyrazole compounds to attain $98.5 \%$ at the $10^{-3} \mathrm{M}$ of $(\mathrm{P} 2)$. The increase in temperature leads to a decrease in the inhibition efficiency of the compounds in the temperature range $308-$ $353 \mathrm{~K}$. The adsorption isotherm of inhibitors on the steel has been determined. The thermodynamic data of activation and adsorption are determined.
\end{abstract}

Keywords: pyrazole, inhibition, corrosion, steel, acid.

\section{Introduction}

Hydrochloric acid is commonly used in industrial processes like chemical cleaning and pickling to remove mill scales (oxide scales) from the metal surface. During this stage, the addition of inhibitor is necessary to avoid the attack of metal. Inhibitors should be effective even under severe conditions in concentrated acid $(20 \%)$ and temperatures ranging from 60 to $95{ }^{\circ} \mathrm{C}$. The most efficient corrosion inhibitors used in chlorhydric acid contain heteroatoms such as sulphur, nitrogen and oxygen containing compounds [1-6].

\footnotetext{
* Corresponding author. E-mail address: hammoutib@yahoo.fr
} 
Survey of literature reveals that azole, azine and pyridine [7-9] compounds are effective corrosion inhibitors up to $80{ }^{\circ} \mathrm{C}$. The synthesis of new organic molecules offers various molecular structures containing several heteroatoms and substituants. Their adsorption is generally explained by the formation of an adsorptive film of a physical or chemical character on the metal surface [10-12]. The encouraging results obtained by pyrazolic compounds [13-17] have incited us to synthesize other compounds and to test their addition on the corrosion behaviour of steel in acidic media.

In the present work, we investigate the corrosion of steel in $1 \mathrm{M} \mathrm{HCl}$ by 1 \{[benzyl-(2-cyano-ethyl)-amino]-methyl $\}-5$-methyl-1H-pyrazole-3-carboxylic acid methyl ester (P1) and 1-\{[benzyl-(2-cyano-ethyl)-amino]-methyl $\}-5$ methyl-1H-pyrazole-3-carboxylic acid ethyl ester (P2); weight loss and polarisation measurements have been used to study the effect of addition of these compounds on the corrosion of steel in $\mathrm{HCl}$ solution. The effect of temperature is also studied and some thermodynamic parameters are evaluated.

\section{Experimental details}

Steel sample containing $0.09 \% \mathrm{P} ; 0.38 \% \mathrm{Si} ; 0.01 \% \mathrm{Al} ; 0.05 \% \mathrm{Mn} ; 0.21 \% \mathrm{C}$; $0.05 \% \mathrm{~S}$ and the remainder iron. Prior to all measurements, the steel samples are polished with different emery paper up to 1200 grade, washed thoroughly with bidistilled water degreased and dried with ethanol, acetone.

The molar hydrochloric solution is prepared by dilution of Analytical Grad 97\% $\mathrm{HCl}$ with bidistilled- water.

Pyrazole compounds were synthesised by aza-type Michael addition [18-19], purified and characterised by N.M.R and mass spectroscopy before use. The molecular structure of the pyrazole studied is shown in Fig. 1.

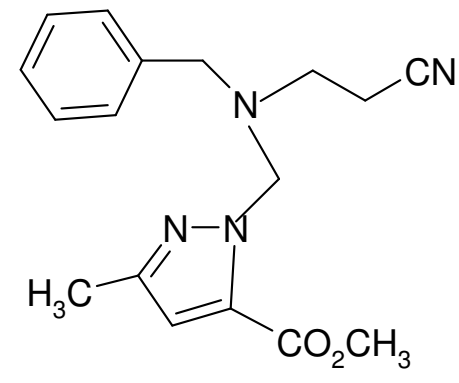

$\mathbf{P}_{1}$

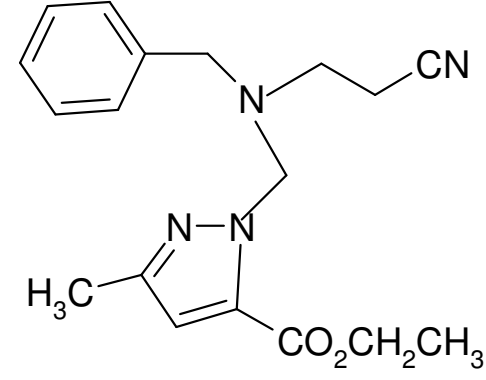

$\mathbf{P}_{2}$

Figure 1. Molecular structure of 1-\{[benzyl-(2-cyano-ethyl)-amino]-methyl $\}-5$-methyl1H-pyrazole-3-carboxylic acid methyl ester (P1) and 1- $\{$ [benzyl-(2-cyano-ethyl)-amino]methyl \}-5-methyl-1H-pyrazole-3-carboxylic acid ethyl ester (P2).

Gravimetric measurements are carried out in double walled glass cell equipped with a thermostatic cooling condenser. The solution volume is $100 \mathrm{~cm}^{3}$. The steel specimens used have a rectangular form $(1.5 \mathrm{~cm} \times 1.5 \mathrm{~cm} \times 0.05 \mathrm{~cm})$. 
Electrochemical trends are carried out in a conventional three electrode cylindrical glass cell. The working electrode, in the form of a disc cut from steel, has a geometric area of $1 \mathrm{~cm}^{2}$. A saturated calomel electrode (SCE) and platinum electrode are used as reference and auxiliary electrode, respectively. The temperature is thermostatically controlled at $308 \mathrm{~K}$. The polarisation curves are recorded with a potentiostat type $E G$ and $G 273$, at a scan rate of $30 \mathrm{mV} / \mathrm{min}$. The steel electrode was maintained at corrosion potential for $30 \mathrm{~min}$ and thereafter prepolarised at $-800 \mathrm{mV}$ for $10 \mathrm{~min}$. The potential was swept to anodic potentials. The test solution is de-aerated for $30 \mathrm{~min}$ in the cell with pure nitrogen which is maintained throughout the experiments.

\section{Results and discussion}

\section{Weight loss measurements}

Table 1 resumes the corrosion rate obtained in $1 \mathrm{M} \mathrm{HCl}\left(\mathrm{W}_{\text {corr }}^{0}\right)$ and at various contents of P1 and P2 ( $\left.\mathrm{W}_{\text {corr }}\right)$ determined at $308 \mathrm{~K}$ after $1 \mathrm{~h}$ of immersion rate and inhibition efficiencies $\mathrm{E}_{\mathrm{w}}$, determined by the relation:

$$
E_{w} \%=100 \times\left(1-\frac{W_{\text {Corr }}}{W_{\text {Corr }}^{\circ}}\right)
$$

where $\mathrm{W}_{\text {corr }}$ and $\mathrm{W}^{\circ}$ corr are the corrosion rates of steel with and without $\mathrm{P} 1$ and $\mathrm{P} 2$, respectively.

Table 1. Gravimetric results of steel in $1 \mathrm{M} \mathrm{HCl}$ with and without addition of the compounds $\mathrm{P} 1$ and $\mathrm{P} 2$ at various concentrations.

\begin{tabular}{cccc}
\hline Inhibitor & Concentration $(\mathrm{M})$ & $\mathrm{W}\left(\mathrm{mg} \cdot \mathrm{cm}^{-2} \cdot \mathrm{h}^{-1}\right)$ & $\mathrm{E} \%$ \\
\cline { 2 - 4 } & Blanc & 1.439 & - \\
\cline { 2 - 4 } P1 & $10^{-6}$ & 1.284 & 10.7 \\
& $10^{-5}$ & 0.991 & 31.0 \\
& $5 \times 10^{-5}$ & 0.147 & 89.7 \\
& $10^{-4}$ & 0.13 & 90.9 \\
& $5 \times 10^{-4}$ & 0.114 & 92.1 \\
& $10^{-3}$ & 0.033 & 97.7 \\
P2 & $10^{-6}$ & 0.71 & 50.7 \\
& $10^{-5}$ & 0.387 & 73.1 \\
& $5 \times 10^{-5}$ & 0.207 & 85.6 \\
& $10^{-4}$ & 0.105 & 92.7 \\
& $5 \times 10^{-4}$ & 0.0738 & 94.9 \\
& $10^{-3}$ & 0.0218 & 98.5
\end{tabular}

It is clear that the addition of compounds reduces the corrosion rate in $\mathrm{HCl}$ solution. The inhibitory effect increases with the increase of pyrazoles derivatives concentration. $\mathrm{E} \%$ reaches a maximum of $98 \%$ at $10^{-3} \mathrm{M}$ for $\mathrm{P} 2$. The effectiveness of P2 is due to the presence of ethyl group which has more inductive effect compared to methyl one in $\mathrm{P} 1$. The protective properties of these 
compounds are probably due to the interaction between $\pi$-electrons of the pyrazole rings and heteroatom with positively charged steel surface [20-21]. We may conclude that compounds are good inhibitors of steel corrosion in $1 \mathrm{M} \mathrm{HCl}$ solution.

\section{Electrochemical polarisation measurements}

In the case of polarisation method the relation determines the inhibition efficiency $(E \%)$ :

$$
E \%=100 \times\left(1-\frac{I_{\text {Corr }}}{I^{\circ}{ }_{\text {Corr }}}\right)
$$

where $\mathrm{I}^{\circ}$ corr and $\mathrm{I}_{\text {corr }}$ are the uninhibited and inhibited corrosion current densities, respectively, determined by extrapolation of cathodic Tafel lines to corrosion potential.

Polarisation behaviour of steel in $1 \mathrm{M} \mathrm{HCl}$ in the presence and absence of inhibitors is shown in Fig. 2. The values of corrosion current $\left(\mathrm{I}_{\text {corr }}\right)$, corrosion potential $\left(\mathrm{E}_{\text {corr }}\right)$, cathodic Tafel slope $\left(\mathrm{b}_{\mathrm{c}}\right)$ and inhibition efficiency $(\mathrm{E} \%)$, are collected in Table 2.

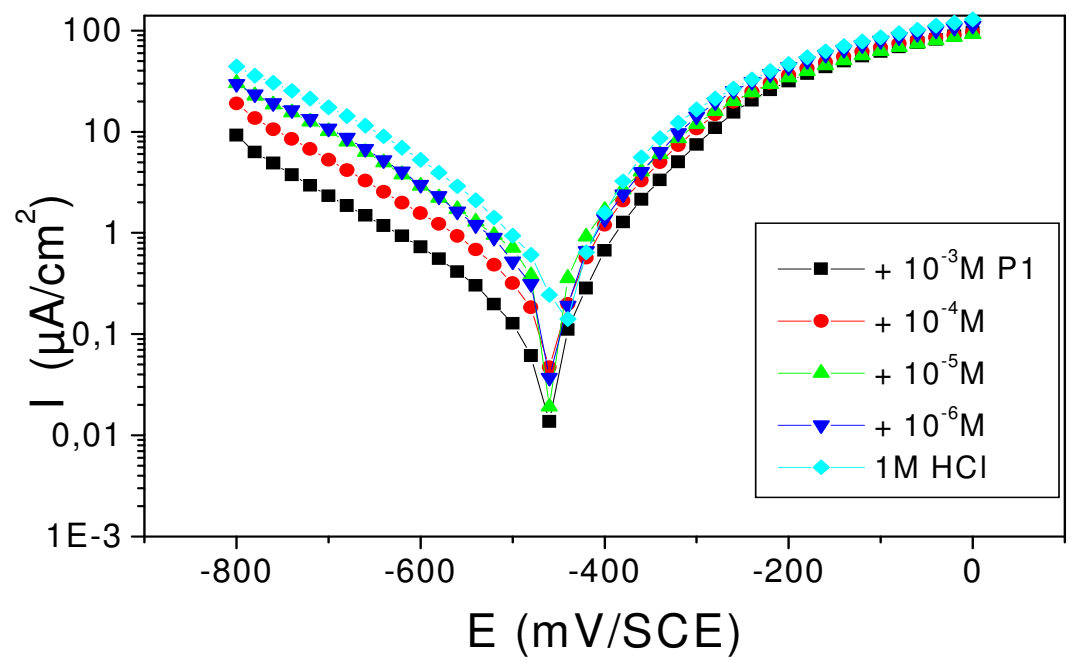

Figure 2. Typical polarisation curves of steel in $1 \mathrm{M} \mathrm{HCl}$ for various concentrations of P1.

The examination of Fig. 2 and Table 2 shows that the addition of P1 and P2 decreases current density. The decrease is more pronounced with the increase of the inhibitor concentration. The Tafel plots indicate that the mechanism of hydrogen reduction is activation control. The presence of pyrazoles does not affect the cathodic Tafel slope, indicating that the mechanism of $\mathrm{H}^{+}$reduction is not modified with the $\mathrm{P} 1$ and $\mathrm{P} 2$ concentration. Also, the corrosion potential is almost constant in the presence of the inhibitors. But in the anodic domain, the i$\mathrm{E}$ characteristics are almost the same. This result indicates that organic compounds act predominantly as cathodic inhibitors by simple blocking the 
available surface area. The inhibitor molecules decrease the surface area of corrosion and only cause inactivation of a part of the surface with respect to the corrosion medium. The inhibition efficiency reaches 90.6 and $91.5 \%$ at $10^{-3} \mathrm{M}$ of $\mathrm{P} 1$ and P2, respectively. This phenomenon is interpreted by the adsorption of the molecules on steel surface leading to the increase of the surface coverage $\theta$ defined by E\%/100. E\% increases with compound concentration. We may conclude that P1 and P2 are effective inhibitors of steel corrosion in molar $\mathrm{HCl}$.

Table 2. Polarisation parameters for steel in acid at different contents of P1 and P2 at $308 \mathrm{~K}$.

\begin{tabular}{|c|c|c|c|c|}
\hline Concentration & $\mathrm{E}_{\text {corr }}(\mathrm{mV})$ & $\mathrm{b}_{\mathrm{c}}(\mathrm{mV} / \mathrm{dec})$ & $\mathrm{I}_{\text {corr }}\left(\mu \mathrm{A} / \mathrm{cm}^{2}\right)$ & $\mathrm{E} \%$ \\
\hline $1 \mathrm{M} \mathrm{HCl}$ & -475 & 178 & 1239.6 & - \\
\hline $10^{-6} \mathrm{M} \mathrm{P} 1$ & -516 & 170 & 1141.6 & 7.9 \\
\hline $10^{-5} \mathrm{M} \mathrm{P} 1$ & -511 & 179 & 916.4 & 26.1 \\
\hline $10^{-4}$ M P1 & -454 & 172 & 234.5 & 81.1 \\
\hline $10^{-3} \mathrm{M} 1$ & -467 & 165 & 116.4 & 90.6 \\
\hline $10^{-6} \mathrm{M} \mathrm{P} 2$ & -480 & 180 & 638 & 48.5 \\
\hline $10^{-5} \mathrm{M} 2$ & -461 & 173 & 397 & 68.0 \\
\hline $10^{-4}$ M P2 & -438 & 184 & 177 & 85.7 \\
\hline $10^{-3} \mathrm{M} 2$ & -454 & 162 & 106 & 91.5 \\
\hline
\end{tabular}

\section{Effect of temperature}

We have studied the temperature influence on the efficiency of P1 an P2. For this purpose, we made weight-loss measurements in the temperature range 313-353 $\mathrm{K}$, in the presence and absence of the compound at various concentrations during $1 \mathrm{~h}$ of immersion. The corresponding data are shown in Table 3.

It is clear that the increase of corrosion rate is more pronounced with the rise of temperature for blank solution. In the presence of the tested molecules, $\mathrm{W}_{\text {corr }}$ is highly reduced. Hence we note that the efficiency depends on the temperature and dercreases with the rise of temperature from 308 to $353 \mathrm{~K}$. This can be explained by the decrease of the strength of the adsorption process at elevated temperature and suggested a physical adsorption mode.

To calculate activation thermodynamic parameters of the corrosion reaction such as the energy Ea, the entropy $\Delta \mathrm{S}^{\circ}$ and the enthalpy $\Delta \mathrm{H}^{\circ}$ of activation, Arrhenius Eq. (2) and its alternative formulation called transition state Eq. (3) were used:

$$
\begin{gathered}
W=K \exp \left(-\frac{E}{R T}\right) \\
W=\frac{R T}{N h} \exp \left(\frac{\Delta S_{\mathrm{a}}^{o}}{R}\right) \exp \left(-\frac{\Delta H_{\mathrm{a}}^{o}}{R T}\right)
\end{gathered}
$$


where $\mathrm{T}$ is the absolute temperature, $\mathrm{K}$ is a constant and $\mathrm{R}$ is the universal gas constant, $\mathrm{h}$ is Plank's constant, and $\mathrm{N}$ is Avogadro's number.

Table 3. Effect of temperature on the corrosion rate of steel at various concentrations of $\mathrm{P} 2$ at $1 \mathrm{~h}$.

\begin{tabular}{ccccc}
\hline Temperature (K) & $\begin{array}{c}\text { Concentration } \\
(\mathrm{M})\end{array}$ & $\begin{array}{c}\mathrm{W} \\
\left(\mathrm{mg} / \mathrm{cm}^{2} . \mathrm{h}\right)\end{array}$ & $\mathrm{E}(\%)$ & $\theta$ \\
\hline \multirow{4}{*}{313} & Blanc & 2.604 & - & - \\
& $5 \times 10^{-5}$ & 0.905 & 65.2 & 0.652 \\
& $10^{-4}$ & 0.460 & 82.3 & 0.823 \\
& $5 \times 10^{-4}$ & 0.242 & 90.7 & 0.907 \\
& $10^{-3}$ & 0.201 & 92.3 & 0.923 \\
\hline \multirow{5}{*}{323} & Blanc & 4.834 & - & - \\
& $5 \times 10^{-5}$ & 1.877 & 61.2 & 0.612 \\
& $10^{-4}$ & 0.965 & 80.1 & 0.801 \\
& $5 \times 10^{-4}$ & 0.574 & 88.2 & 0.882 \\
& $10^{-3}$ & 0.482 & 90.0 & 0.900 \\
\hline & Blanc & 8.7815 & - & - \\
& $5 \times 10^{-5}$ & 3.998 & 54.5 & 0.545 \\
& $10^{-4}$ & 2.824 & 67.8 & 0.678 \\
& $5 \times 10^{-4}$ & 1.598 & 81.8 & 0.818 \\
& $10^{-3}$ & 0.969 & 89.0 & 0.890 \\
\hline \multirow{4}{*}{343} & Blanc & 13.235 & - & - \\
& $5 \times 10^{-5}$ & 9.372 & 29.2 & 0.292 \\
& $10^{-4}$ & 7.971 & 39.8 & 0.398 \\
& $5 \times 10^{-4}$ & 4.927 & 62.8 & 0.628 \\
& $10^{-3}$ & 3.562 & 73.1 & 0.731 \\
\hline & Blanc & 26.552 & - & - \\
& $5 \times 10^{-5}$ & 21.176 & 20.2 & 0.202 \\
& $10^{-4}$ & 20.049 & 24.5 & 0.245 \\
& $5 \times 10^{-4}$ & 11.205 & 57.8 & 0.578 \\
& $10^{-3}$ & 9.588 & 63.9 & 0.639 \\
\hline & & & &
\end{tabular}

The activation energy $E_{a}$ is calculated from the slope of the plots of $\ln \left(W_{\text {corr }}\right)$ vs. $1 / \mathrm{T}$ (Fig. 3). Plots of $\ln \left(\mathrm{W}_{\text {corr }} / \mathrm{T}\right)$ vs. $1 / \mathrm{T}$ give a straight line with a slope of $\Delta \mathrm{H}^{\circ} / \mathrm{R}$ and an intercept of $\left(\log (\mathrm{R} / \mathrm{Nh})+\Delta \mathrm{S}^{\circ} / \mathrm{R}\right)$, as shown in Fig. 4. From this relation the values of $\Delta \mathrm{H}^{\circ}$ and $\Delta \mathrm{S}^{\circ}$ can be calculated (Table 4).

The decrease of $\mathrm{P} 1$ and $\mathrm{P} 2$ efficiencies with temperature rise leads to a higher value of $\mathrm{E}_{\mathrm{a}}$, when compared to that in an uninhibited acid, and it is interpreted as an indication of an electrostatic character of the inhibitor's adsorption [22]. But, Ea variation is not the unique parameter to affirm of such mode of adsorption. Other ones can be considered, such as free adsorption enthalpy $\Delta G_{\text {ads }}^{0}$ and enthalpy $\Delta \mathrm{H}_{\text {ads }}^{0}$, which will be discussed in next paragraph. The positive values of $\Delta \mathrm{H}^{\circ}$ mean that the dissolution reaction is an exothermic process and that the dissolution of steel is difficult [23]. Practically $\mathrm{E}_{\mathrm{a}}$ and $\Delta \mathrm{H}^{\circ}$ are of the same order. Also, the entropy $\Delta \mathrm{S}^{\circ}$ increases more positively with the presence of the inhibitor 
than in the presence of the non-inhibited one. This reflects the formation of an ordered stable layer of the inhibitor on the steel surface [24]. From the previous data, we can conclude that $\mathrm{P} 2$ is an effective inhibitor.

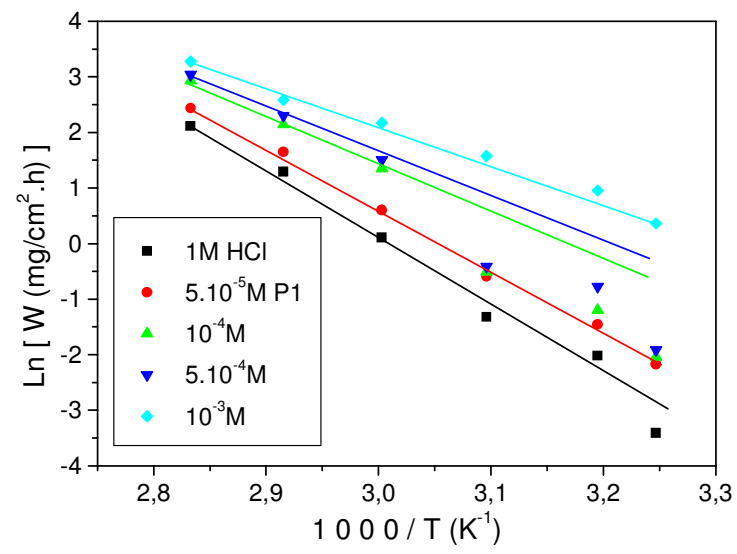

Figure 3. Typical Arrhenius plots for $\log \mathrm{W}$ vs. 1 / $\mathrm{T}$ for steel in $1 \mathrm{M} \mathrm{HCl}$ at different concentrations of P1.

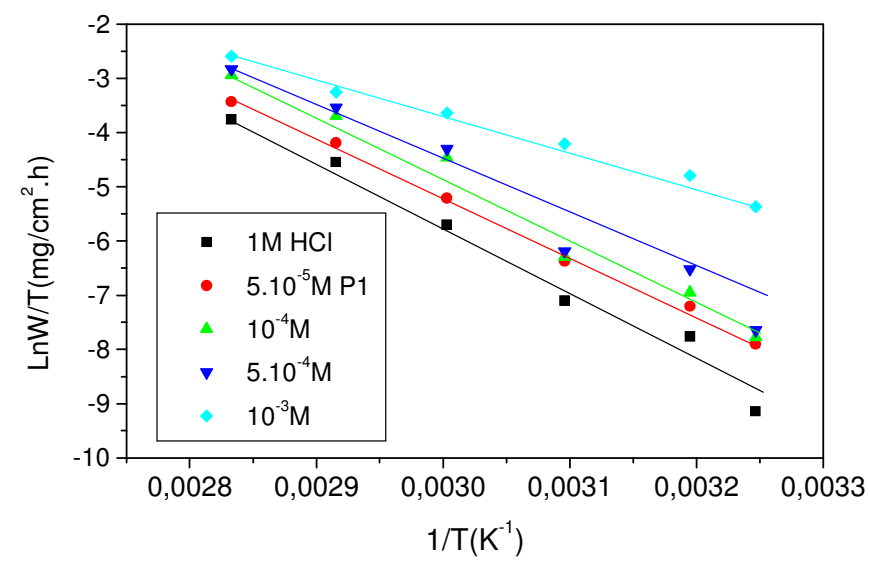

Figure 4. The relation between $\log (W / T)$ vs. $1 / T$ for steel at different concentrations of P1.

Table 4. Activation parameters of the dissolution of steel in $1 \mathrm{M} \mathrm{HCl}$ in the absence and presence of $\mathrm{P} 1$ and $\mathrm{P} 2$.

\begin{tabular}{ccccc}
\hline $\mathrm{C}(\mathrm{M})$ & $\begin{array}{c}E_{\mathrm{a}} \\
(\mathrm{kJ} / \mathrm{mol})\end{array}$ & $\begin{array}{c}\Delta \mathrm{H}_{\mathrm{a}}^{\circ} \\
(\mathrm{kJ} / \mathrm{mol})\end{array}$ & $\begin{array}{c}\Delta \mathrm{S}_{\mathrm{a}}^{\circ} \\
(\mathrm{J} / \mathrm{mol} . \mathrm{K})\end{array}$ & $\begin{array}{c}\mathrm{E}_{\mathrm{a}}-\Delta \mathrm{H}_{\mathrm{a}}^{\circ} \\
(\mathrm{kJ} / \mathrm{mol})\end{array}$ \\
\hline Blank & 55.27 & 52.5 & -70.6 & 2.7 \\
$5 \times 10^{-5} \mathrm{P} 1$ & 99.18 & 96.4 & 53.3 & 2.7 \\
$10^{-4} \mathrm{P} 1$ & 101.83 & 99.1 & 59.8 & 2.7 \\
$5 \times 10^{-4} \mathrm{P} 1$ & 92.95 & 90.2 & 29.7 & 2.7 \\
$10^{-3} \mathrm{P} 1$ & 107.33 & 104.6 & 68.4 & 2.7 \\
$5 \times 10^{-5} \mathrm{P} 2$ & 84.59 & 81.8 & 11.4 & 2.7 \\
$10^{-4} \mathrm{P} 2$ & 98.55 & 95.8 & 50.4 & 2.7 \\
$5 \times 10^{-4} \mathrm{P} 2$ & 96.90 & 94.2 & 41.0 & 2.7 \\
$10^{-3} \mathrm{P} 2$ & 93.15 & 90.4 & 27.7 & 2.7 \\
\hline
\end{tabular}




\section{Adsorption isotherm}

Fig. 5 shows the linear dependence of $\theta / 1-\theta$ as a function of concentration $\mathrm{C}$ of the inhibitors, where $\theta$ is the surface coverage determined by the ratio $E \% / 100$. Inhibitor adsorbs on the steel surface according to the Langmuir kind isotherm model which obeys the relation:

$$
\text { (5) } \frac{\theta}{1-\theta}=K C
$$

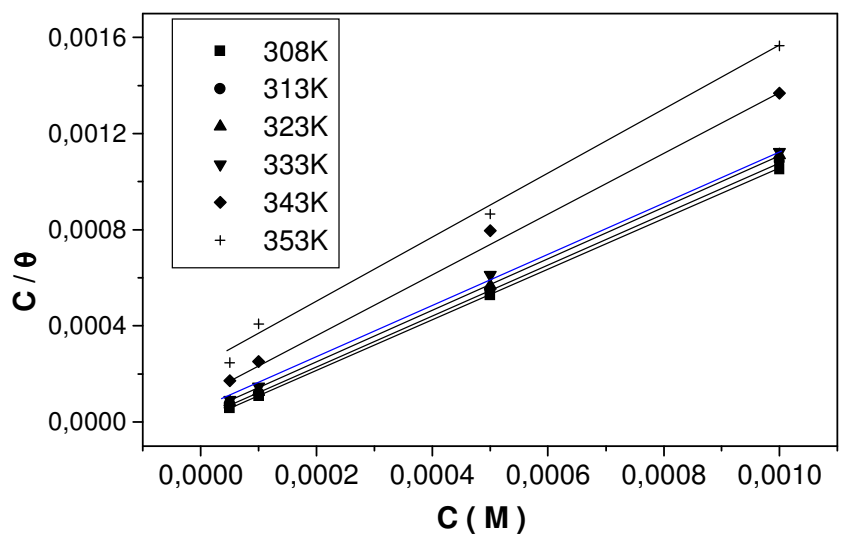

Figure 5. Fitting Langmuir's adsorption isotherm model for $\mathrm{P} 2$ in $1 \mathrm{M} \mathrm{HCl}$ at different temperatures.

The thermodynamic parameters for adsorption given in Table 5 were calculated using the values of $\mathrm{K}$ according to the following relations:

$$
\begin{array}{r}
\ln (K)=-\frac{\Delta H_{a d s}^{\circ}}{\mathrm{R} \mathrm{T}}+\text { Constant } \\
K=\frac{1}{55.5} \exp \left(-\frac{\Delta \mathrm{G}^{\circ}}{\mathrm{RT}}\right) \\
\frac{\Delta G_{a d s}^{\circ}}{T}=\frac{\Delta H_{a d s}^{\circ}}{T}+A \\
\Delta \mathrm{G}^{\circ}{ }_{\text {ads }}^{\circ}=\Delta \mathrm{H}^{\circ}{ }_{\text {ads }}-\mathrm{T} \Delta \mathrm{S}^{\circ}{ }_{\text {ads }}
\end{array}
$$

where $\Delta \mathrm{S}_{\text {ads }}^{0}$ and $\Delta \mathrm{H}_{\text {ads }}^{0}$ are the entropy and the enthalpy of activation, respectively. From this relation the values of $\Delta \mathrm{H}^{0}{ }_{\text {ads }}, \Delta \mathrm{S}_{\text {ads }}^{0}$ and $\Delta \mathrm{G}_{\text {ads }}^{0}$ can be calculated (Table 5).

The negative values of $\Delta \mathrm{G}^{\circ}$ ads suggest that the adsorption of P2 molecule onto the steel surface is a spontaneous process and the adsorbed layer is stable. Generally values of $\Delta \mathrm{G}^{\circ}$ ads around $-20 \mathrm{~kJ} / \mathrm{mol}$ or lower are consistent with the electrostatic interaction between the charged molecules and the charged metal (physisorption), those around $-40 \mathrm{~kJ} / \mathrm{mol}$ or higher involve charge transfer from organic molecules to the metal at the surface to form a coordinate type of bond (chemisorption) [25-27]. The calculated $\Delta \mathrm{G}_{\text {ads }}^{\circ}$ close $-40 \mathrm{~kJ} / \mathrm{mol}$ indicates that 
chemisorption is a probable process. But, values of other thermodynamic parameter as $\Delta \mathrm{H}_{\mathrm{ads}}$ can provide supplementary information about the mechanism

Table 5. Thermodynamic data for studied P2 from experimental adsorption isotherm.

\begin{tabular}{|c|c|c|c|c|}
\hline Temperature (K) & $K$ & $\begin{array}{c}\Delta \mathrm{G}_{\text {ads }}^{\circ} \\
\left(\mathrm{kJ} \mathrm{mol}^{-1}\right)\end{array}$ & $\begin{array}{c}\Delta \mathrm{H}^{\circ}{ }_{\text {ads }} \\
\left(\mathrm{kJ} \mathrm{mol}^{-1}\right)\end{array}$ & $\begin{array}{c}\Delta \mathrm{S}_{\text {ads }}^{\circ} \\
\left(\mathrm{J} \cdot \mathrm{mol}^{-1} \mathrm{~K}^{-1}\right)\end{array}$ \\
\hline 308 & 230360.1 & -41.93 & & \\
\hline 313 & 51724.2 & -38.72 & & \\
\hline 323 & 45284.5 & -39.60 & -70.85 & -97.4 \\
\hline 333 & 22793.7 & -38.92 & & \\
\hline 343 & 7853.0 & -37.06 & & \\
\hline
\end{tabular}

of corrosion inhibition. While an endothermic adsorption process $\left(\Delta \mathrm{H}_{\mathrm{ads}}>0\right)$ is attributed unequivocally to chemisorption, an exothermic adsorption process $\left(\Delta \mathrm{H}_{\mathrm{ads}}<0\right)$ may involve either physisorption or chemisorption or a mixture of both processes [28, 29]. In the present work, the negative value obtained may introduce a mixture of both chemisorption and physisorption processes. This may be interpreted by the presence of both heteroatoms (four nitrogen and two oxygen atoms) which lead to coordinate bonds and aromatic rings which get physisorption. Also the negative values of $\Delta \mathrm{H}^{\circ}$ ads show that the adsorption is exothermal with an ordered phenomenon ascribed by the negative values of $\Delta \mathrm{S}^{\circ}$ ads. This order may more probably be explained by the possibility of formation of iron complex on the metal surface [30, 31].

\section{Conclusions}

From the overall experimental results the following conclusions can be deduced:

- The 1-\{[benzyl-(2-cyano-ethyl)-amino]-methyl $\}-5$-methyl-1H-pyrazole-3carboxylic acid methyl ester (P1) and 1-\{[benzyl-(2-cyano-ethyl)-amino]methyl -5-methyl-1H-pyrazole-3-carboxylic acid ethyl ester (P2) are efficient inhibitors for the corrosion of steel in $1 \mathrm{M} \mathrm{HCl}$.

- The inhibition efficiency of P2 increases with the concentration to attain a maximum value $98.5 \%$ at $10^{-3} \mathrm{M}$.

- P1 and P2 act as cathodic inhibitors with modifying the hydrogen reduction mechanism.

- The inhibition efficiency of P1 and P2 decreases with the rise of temperature.

- The activation and adsorption thermodynamic parameters are determined.

\section{References}

1. G. Mengoly, M.M. Musiani, C. Pagura, F. Paoulucci, Corros. Sci. 31 (1991) 743.

2. D. Bouzidi, S. Kertit, B. Hammouti, M. Brighli, J. Electrochem. Soc. India 46 (1997) 23.

3. S. Kertit, K. Bekkouch, B. Hammouti, Revue de Métallurgie (Paris) 97 (1998) 251. 
4. Y. Abed, B. Hammouti, F. Touhami, A. Aouniti, S. Kertit, A. Mansri, K. Elkacemi, Bull. Electrochem. 17 (2001) 105.

5. F.B. Growcock, V.R. Lopp, Corros. Sci. 28 (1998) 397.

6. G. Quartarone, T. Bellomi, A. Zingales, Corros. Sci. 45 (2003) 715.

7. M. Bouklah, A. Attayibat, B. Hammouti, A. Ramdani, S. Radi, M. Benkaddour, Appl. Surf. Sci. 240 (2005) 341.

8. A. Aouniti, B. Hammouti, S. Kertit, Bull. Electrochem. 14 (1998) 193.

9. $\quad$ K.M. El-Sobki, H. Abbas, React. Solids 5 (1988) 191.

10. G. Subramaniam, K. Balasubramanian, P. Sridhar, Corros. Sci. 30 (1990) 1019.

11. Y. Xiao-Ci, Z. Hong, L. Ming-Dao, R. Hong-Xuan, Y. Lu-An, Corros. Sci. 42 (2000) 645.

12. M. Lashkari, M.R. Arshadi, Chem. Phys. 299 (2004) 131.

13. M. Benabdellah, R. Touzani, A. Aouniti, A. Dafali, S. El Kadiri, B. Hammouti, M. Benkaddour, Mater. Chem. Phys. (2007). In press.

14. K. Tebbji, I. Bouabdellah, A. Aouniti, B. Hammouti, H. Oudda, M. Benkaddour and A. Ramdani, Materials Letters 61 (2007) 799.

15. A. Chetouani, M. Daoudi, B. Hammouti, T. Ben Hadda and M. Benkaddour, Corros. Sci. 48 (2006) 2987.

16. K. Tebbji, B. Hammouti, H. Oudda, A. Ramdani and M. Benkadour, Appl. Surf. Sci. 252 (2005) 1378.

17. M. Elayyachy, M. Elkodadi, A. Aouniti, A. Ramdani, B. Hammouti, F. Malek, A. Elidrissi, Mater. Chem. Phys. 93 (2005) 281.

18. L. Herrag, R. Touzani, A. Ramdani, B. Hammouti, Molbank 2006, M493

19. L. Herrag, R. Touzani, A. Ramdani, B. Hammouti, Molbank 2006, M494

20. A. Chetouani, B. Hammouti, A. Aouniti, N. Benchat, T. Benhadda, Prog. Org. Coat. 45 (2002) 373.

21. A. Chetouani, A. Aouniti, B. Hammouti, N. Benchat, T. Benhadda, S. Kertit, Corros. Sci. 45 (2003) 1675.

22. A. Popova, Corros. Sci. 49 (2007) 2144.

23. N.M. Guan, L. Xueming, L. Fei, Mater. Chem. Phys. 86 (2004) 59.

24. A. Yurt, A. Balaban, S.U. Kandemir, G. Bereket, B. Erk, Mater. Chem. Phys. 85 (2004) 420.

25. M. Bouklah, N. Benchat, B. Hammouti, A. Aouniti, S. Kertit, Materials Letters 60 (2006) 1901.

26. F.M. Donahue, K. Nobe, J. Electrochem. Soc. 112 (1965) 886.

27. E. Khamis, F. Bellucci, R.M. Latanision, E.S.H. El-Ashry, Corrosion 47 (1991) 677.

28. W. Durnie, R.D. Marco, A. Jefferson, B. Kinsella, J. Electrochem. Soc. 146 (1999) 1751.

29. S.A. Ali, A.M. El-Shareef, R.F. Al-Ghamdi, M.T. Saeed, Corros. Sci. 47 (2005) 2659.

30. M. Abdallah and M. M. El-Naggar, Mater. Chem. Physics 71 (2001) 291.

31. A. Bousseksou, G. Molnár, J.A. Real, K. Tanaka, Coord. Chem. Rev. 251 (2007) 1822. 